\title{
KUVÂY-I İNZİBÂTIYYE
}

\author{
Yrd. Doç. Dr. Günay ÇAĞLAR*
}

30 Ekim 1918 Mondros Mütarekesi'nin imzalanmasıyla, I'tilaf Devletleri Türk topraklanı üzerindeki planlannı hızlı bir şekilde uygulamaya başladılar. Bu uygulamalardan son derece rahatsız olan Türk Milleti, memleketin dört bir tarafında mahallî kurtulus gayelerine yönelik millî́ cemiyetler oluşturdu. 15 Mayıs 1919 'da İzmir'in Yunanlılar tarafından işgali üzerine, halkın I'tilâf Devletleri'ne karşı tepkisi büyürken, Amasya Genelgesi ve kongrelerle Kuvây-1 Millîye ruhu teşkilâtlı bir karşı koyma şeklini alıyordu. 16 Mart 1920 'de İstanbul'un resmen işgali dolayısıyla, T.B.M.M.'nin açılması karşısında, İngilizler'in direktifleri doğrultusunda, Sadrazam Damad Ferid Paşa Kuvây-1 Milliye'ye karşı bazı tedbirler aldırmaya başladı.

26 ve 31 Mart günlerinde, Hükûmet'e iki nota veren I'tilaf Devletleri Yüksek Komiserleri, Kuvây-1 Milliye'nin resmen red ve mahkûm edilmesini istediler ${ }^{1}$. Salih Paşa, 29 Mart'ta bu millî harekâtın doğal haklann savunulması olduğu cevabinı verince, İngiliz Yüksek Komiseri Amiral J De Robeck bu karşılıktan Mustafa Kemâl Paşa'nın onaylandığı anlamını çıkardı. 1 Nisan'da da uzun bir nota ile işgal kuvvetlerince yapılan hukuka aykırı uygulamalar protesto edilince ${ }^{2}$, ortam iyice gerginleşti. Bu arada, Salih Paşa Hükûmeti'nin istifası üzerine, tekrar Damad Ferid Paşa devri geldi $^{3}$. Ve 11 Nisan'da I'tilâf kuvvetlerini memnun edecek kararlar alındı. Şeyhülislâm Dürrizâde Abdullah'ın 10 Nisan tarihli fetvâsı ${ }^{4}$, Damad Ferid Paşa'nın hazırlattığı Hükûmet Beyânnâmesi ve Padişah'ın 5 Nisan'da Damad Ferid Paşa'ya vermiş olduğu ferman yayınlandı ${ }^{5}$. Türk milliyetçilerini hain ilân edip, cezalandınlmalarını içeren bu üç metin bir arada basılarak, I'tilâf kuvvetleri uçaklanyla Anadolu'ya dağıtılıp, halkın dini duyguları istismar edildi. Diğer faktörlerle birlikte, bu silâhlann da

* Atatürk Universitesi Fen-Edebiyat Fakültesi Tarih Bölümü.

1. Gotthard Jaeschke, Kurtuluş Savaşı ile Ilgili Ingiliz Belgeleri. (Çev: Cemal Köprülü), Ankara 1971, S.153.

2. a.y.

3. a.y.

4. a.y.

5. Takvim-i Vekâyi, 11 Nisan 1920, S.3824. 
büyük etkisiyle, Anadolu'ya Kuvây-1 Milliye'ye karşı bir ayaklanma dalgasi meydana geldi.

Ankara Müftüsü Mehmet Rıfat'ın 16 Nisan tarihli karşı fetvâsı ${ }^{6}$ ise, büyüyen yangını söndürmede pek faydalı olamadi?

Ankara'da açılacak yeni Meclis'te bulunabilmek gayesiylè, İstanbul'da bulunan milletvekili, kumandan ve subaylarnn Anadolu'da toplandığ1 günlerde, Amiral J. De Robeck'i ziyaret eden Damad Ferid Paşa; Anadolu'daki millî harekâtın bastırlabilmesi için, kuvvetle karşıı konulması gerektiğini, bu konuda I'tilâf Devletleri'nin kendisine ne ölçüde yardım edebileceklerini sordu. Bunun üzerine Amiral; Anadolu'daki millî kuvvetlere karşı İngiliz'lerin bir harekette bulunamayacaklarını, fakat onlara karşı kurulacak bir teşkilâta yardımda bulunabileceklerini ifade etti ${ }^{8}$. Türkiye'yi millî kuvvetleri bastırarak ve Türk'ü Türk'e kırdırarak parçalamayı düşünen İngiltere, bu konuda hemen hazırlığa başladı

İngiliz casusluk yuvası konumunda bulunan İngiliz Muhîbleri Cemiyeti vakit kaybetmeden çalışmaya başlamış, kurulması düşünülen orduya maddî destek vermiştir ${ }^{10}$. Kısa bir süre sonra Hürriyet ve İ'tilâf Fırkasi, Nigehbancılar ve Kızılhançerliler de İngiliz Muhîbleri Cemiyeti'nin çalışmalarına katıldılar. İngilizler, Damad Ferid ve yandaşlanını kısa süreli çalışmaları sonucunda, Kuvây-1 İnzibâtiye adlı ordunun kuruluş kararnamesi, 18 Nisan 1920 'de Hükûmet tarafindan onaylandı. 18 maddelik bu kararnâme 24 Nisan 1920 tarih ve 3835 sayılı Takvim-i Vekâyi'de yayınlandı. Söz konusu kararname ile, jandarma kuvvetlerine benzer ve gönüllülerden oluşan Kuvây-i Inzibâtiyye'nin kurulması kararlaştırıldı. Kuvây1 Milliye'yi yok etmek amaciyla kurulan Kuvây-1 İnzibâtiye, Dâhiliye ve Harbiye Nezâretleri'ne bağlı olup, subaylar, görevli ve emekli olanlarla gönüllülerden oluşuyordu.

Kuvây-1 İnzibatiye Kumandanlı̆̆ı'na Ordu Kumandanı yetkisiyle, Süleyman Şefik Paşa" getirilerek, "İzmit ve Havâlisi Fevkalâde Kumandanlığı"da kendisine verilmiştir.

6. Jaeschke, Kurtuluş Savaşı ile llgili Ingiliz Belgeleri, S.153.

7. 11 Mays' ta Birinci Idâre-i Orfiyye Mahkemesi'nin Mustafa Kemâl Paşa ile arkadaşları hakkında verdiği idam kararı (Bkz. Takvim-i Vekâyi, 24 Mayıs 1336, S.3864) 24 Mayıs'ta Padişah tarafından onaylanmıştir. (Bkz. Belgelerle Türk Tarihi Dergisi, S.I, Belge. 6).

8. Selahattin Tansel, Mondros'tan Mudanya'ya Kadar III, Ankara 1968, S.108.

9. Kâzım Karabekir, Istiklâl Harbimiz, Istanbul 1988, S.662.

10. Mustafa Kemâl Atatürk, Nutuk I, Istanbul 1967, S.212-17.

11. Süleyman Şefik Paşa'nın, Ali Galip Olayı esnasında, Harbiye Nazın olarak takınmış olduğu olumsuz tavırlar yüzünden: M. Kemâl Paşa, Ali Rıza Paşa Hükûmeti kurulduktan sonra, onun Yüce Divan'a verilmesini istedi. (Bkz. S. Nabi Ozerdim, Açklamalı Söylev Sözlügü, Ankara 1981, S.84) Nisan 1920 'de Kuvây-1 Inzibatiyye ile Izmit ve 
Süleyman Şefik Paşa'nın vazifesine ve salâhiyet ve tahkikâta yönelik olarak düzenlenen ta'limatnãme, 2 Mayıs 1920'de Damad Ferid Paşa tarafından Padişah'a arz edilmiştir ${ }^{12}$.

"Harbiye Nezâreti

Nezâret Şubesi

Kalem-i Mahsûs

Ma'rûz-1 Çâker-i kemîneleridir ki,

İzmit ve Havâlisi Fevkalâde Kumandanlığı'na ta'yin buyurulan Yâver-i Ekrem Hazret-i Şehriyânî Ferik Süleyman Paşa Hazretleri'nin vazifesine ve salâhiyet ve tahkikâta müteallik olarak tanzîm edilen ta'limatname leffen Pişgâh-1 Sâmî-i fehimânelerine takdîm kılınmıs olmağla lede't-tedkîk takrib-i âlî-i sadâretpenâhilerine iktirân eylediği sûretde iktizâsının ifâ ve neticesinin, emr ve inba buyurulması ma'rûzdur. Olbabda emr-i ferman hazret-i veliyyü'l-emrindir.

Fî 12 Saban 338, fi 2 Mayıs 336. Sadrazam ve Harbiye Nâzırı Vekili Damad Ferid Paşa"

5 Mayıs '1920'de söz konusu ta'limatnâme Meclis-i Mahsûs'da görüşülüp, uygun görülerek, Padişah'a arz edilmiştir ${ }^{13}$.

"Bâb-1 Âlî

Meclis-i Mahsûs

104

Harbiye Nezâreti Vekâletin'den vârid olub miyâne-i bendegânemizde melfûfiyle mütalâ'a olunan tezkerede muharrer olduğu vechile İzmit ve Havâlisi Fevkalâde Kumandanlığı'na tayin buyurulmuş olan Yâver-i Ekrem Hazret-i Şehr-iyârî Ferik Süleyman Şefik Paşa'nın vazifesini ve salâhiyet ve tahsîsâtını mutazammın tanzîm edilen ta'limatnâme münderecâtı icâb-1 hâl ve maslahata muvafık görünmüş olduğundan ifâ'y-1 muktezâtı menût-1 müs'ade-i seniyye-i cenâb-1 cihanbânî olduğu bi't-tezekkür kaleme alınan irâde-i seniyye lâ'ihası salifü'l-arz tezkere ve tâ'limatnâme ile beraber arz ve takdîm olunmakla katâbe-i ahvâlde emr ü ferman hazret-i veliyyü'l-emr efendimizindir.

fi 15 Şaban 1338, fi 5 Mayıs 1336

Havâlisi Fevkalâde Kumandanlığı'na tayin edildi. Başansızlığı üzerine, Istanbul'a çağnlinca, 21 Mayıs'ta Izmit'ten ayrıldı. 10 Haziran'da görevine son verildi. Istiklâl Harbi'nden sonra, "Egypt" vapuruyla Mısır'a kaçtı. (Bkz. Tark Mümtaz Göztepe, Osmanoğullarının Son Padişahı Vahdettin Gurbet Cehenneminde, Istanbul 1968, S.43) Yüzelliliklerdendir (Bkz. Ilhami Soysal, 150'likler, Istanbul 1988, S.290).

12. BOA, DUIT, Dosya No.15-3, Gömlek No.4-3. Bkz. Ek.I.

13. BOA, DUIT, Dosya No.15-3, Gömlek No.4-3. Bkz. Ek.II. 


$\begin{array}{ll}\begin{array}{l}\text { Şurây-1 Devlet Reis Vekili } \\ \text { Şeyhü'l-İslâm ve Maarif }\end{array} & \text { Bahriye Nazırı } \\ \text { Nâzın Vekili } & \begin{array}{l}\text { Sadr-1 azam ve Hariciye Nâzın ve } \\ \text { Harbiye Nazın Vekili }\end{array} \\ \begin{array}{l}\text { Evkaf-1 Hümayun Nâzın ve } \\ \text { Nafia Nazır Vekili }\end{array} & \text { Ticaret ve Ziraat Nâzın } \\ \begin{array}{l}\text { Maliye Nazın ve Dâhiliye } \\ \text { Nâzın Vekili }\end{array} & \text { Adliye Nazın" }\end{array}$

Bu ta'limatnâme ile ilgili İrâde-i Seniyye 6 Mayıs 1920 tarihli olup, metni aşă̆ıda verilmiştiti ${ }^{14}$ :

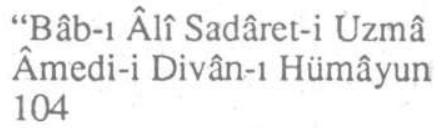

İrâde-i Seniyye Mehmed Vahideddin

İzmit ve Havâlisi Fevkalâde Kumandanı Yaver-i Ekrem Süleyman Şefik Paşa'nın vazifesini ve salâhiyet ve tahsisâtını mütezammın merbût ta'limatnâmenin tatbîk-i ahkâmına Meclis-i Vükelâ kararıyla ruhsat verilmiştir.

Bu irâde-i seniyyenin icrâsına Harbiye Nâzın me'murdur.

fi 6 Mayls 1336 - fi 16 Şaban 1338

Şûra-yı Devlet Reisi Vekili $\quad$ Bahriye Nâzırı Mehmed Said

Şeyhülislâm ve Maarif

Sadrazam ve Hariciye Nâzın ve

Nâzın Vekili Harbiye Nâzın Vekili Damad Ferid

Evkâf-ı Humâyun Nâzın ve

Ticaret ve Ziraat Nâzın

Nafia Nâzın Vekili Osman...

Maliye Nâzın ve Dâhiliye Adliye Nâzın"

Nâzın Vekili

İzmit ve Havâlisi Fevkalâde Kumandanı Süleyman Şefik Paşa'nın yetkilerini belirleyen 6 Mayıs 1920 günlü ta'limatnâmenin metni aşağıda verilmiş ${ }^{15}$ :

14. BOA, DUIT, Dosya No.15-3, Gömlek No.4-3. Bkz. Ek.III.

15. BOA, DUIT, Dosya No.15-3, Gömlek No.4-3. Bkz. Ek.IV. 


\section{"Harbiye Nezâreti \\ Nezâret Şubesi \\ Kalem-i Mahsûs}

İzmit ve Havâlisi Fevkalâde Kumandanlığı'na ta'yin buyurulan Ferik Süleyman Şefik Paşa'nın vazife ve salâhiyetine dair ta'limatnâme

Ünvan-1- Ordu Kumandanı salâhiyet ve muhassesatıyla İzmit ve Havâlisi Fevkalâde Kumandanı

Ma'iyeti-2-Erkân-1 harbiyesi, idare hey'eti, yaverân, sivil kâtib-i hususî emrberler

Vazife-3-Harekât-1 bağiyeyi def ve tenkîl etmek, Kuvây-1 İnzibâtiye'yi vücuda getirmek ve bunlan teşkîl, zabitanın intihab etmek.

Salâhiyeti-4-Harekât ve icrâatında müstakil olmak ve muhaberece sadaret-i uzmâ ve Harbiye Nezareti'ne merbût bulunmak, divan-1 harblerden sâdır olacak hükümleri [i'dâma dair olanlar müstesna olmak üzere] ba'del-icrâ arz ve inhâ etmek ve icab edenleri tarik-i hak ve sevâba dâvet için muhaberâta me'zun ve bunlardan dehâlet edecekleri affa muktedir bulunmak, kıta'at-1 askeriyeye memur erkân, ümerâ ve zâbıtan-1 azı ve tebdîl ve tecziye ve [ezgayr-1 rütbe] mükâfata me'zun bulunmak.

Tahsisat-5 Kumandanlık emrinde mesarif-i gayr-i melhûzadan şimdilik onbin lira bulunmak.

6- Kumandanlığa muhassesat-1 resmiyesinden başka tahsisat olarak mahiye beşyüz lira verilmek.

7- Karargâh için icâb eden eşya, çadır, eğer vesâire (saraçhâne) ve silâhhane anbarlarından verilir. yon"

8- İki takım telsiz telgraf, üç takım helyosta, iki binek, on-iki kam-

18 Nisan 1920 tarihli, Kuvây-1 İnzibâtiye'nin kuruluşu ile ilgili kararname, 6 Mayıs 1920 günlü Süleyman Şefik Paşa'nın salâhiyetlerini ortaya koyan ta'limatnamelerden sonra, sıra söz konusu Ordu'nun asker ihtiyacını karşılamaya geliyordu.

Bu yüzden, Damad Ferid Paşa 23 Nisan'da bir beyânnâme yayınlayarak; İstanbul'da görevde ve açıkta bulunan bütün subayların Harbiye Nezâreti'ne gelerek, yoklama yaptırmalan, gelmeyenlerin askerlikle ilgili her türlü ilişkilerinin kesileceği ve seferberlikten kaçmış sayılarak, Divan-1 Harb'e verileceklerini duyurdu ${ }^{16}$.

16. Karabekir, a.e., S.663. 
İstanbul'un her tarafinda mahalle muhtarlanna verilen beyânnâmelerde Kuvây-1 İnzibatiye'ye gönüllü asker yazılması istenildi ${ }^{17}$. Öyle anlaşlıyor ki, Kuvây-i İnzibâtiye'nin kuruluşunda, Ordunun ihtiyacı daha çok gönüllülerden sağlanmak istenmiştir. Damad Ferid Paşa, bu yolla kadrolanın tamamlayacağını tasarlamaktadır. Nitekim, Sadrazam, Dâhiliye Nezâreti'ne gönderdiği 3 Mayıs 1920 tarihli yazıda bu konuda aşağıda yazılanlan ifade ediyordu ${ }^{18}$.

"Harbiye Nezâreti

Karargâh-1 Erkân-1

Harbiyesi

242

Dâhiliye Nezâreti Celilesine

\section{Devletlü Efendim Hazretleri}

Makam-1 hilâfet-i uzmâya ve hükûmet-i seniyyeye karşı isyân etmiş olan bâğilerin tenkîli ve asayîş-i memleketi şu mühim onlarda temin için merkez-i hilâfet ve saltanatdan henüz Kuvây-1 İnzibâtiye teşkil ve sevk edilememiş olan yerlerde, Kuvây-1 İnzibâtiye hakkındaki kararname ahkâmına tevkifan teşekkül etmekte bulunan gönüllü kıtaâtının ber mucib-i kararname tesviye-i muhassısâtı ve bunlanın kadrolanna ve mikdar ve efrâdına nazaran, alay, tabur, bölük halinde sûret-i teşekkülünün mahallî en büyük mülkiye memurunun riyâset-i tahtında teşkil edilecek heyet tarafindan ba-mazbata tasdike vabeste idügünden, karamame tarihinden sonra, teşekkül eden mezkûr kıtâatın bu suretle tasdik-i memuriyetlerini mutazammın mazbatanın tanzimi ve teşekkül eden kıtaât-ı zâbitan ve efrâd mevcudunun nezâret-i senâveriye işân ve bu suretle teşekkül edecek muntazam kıtaâtın muhassısatlarının mahallî mal memurlannca ve en büyük mülkiye memurlannın i'tâ emirleriyle derhal tesviyei tahsisatlanna başlanmak ve teşkilât ve efrâd ve zâbıtanında akçe miktarlarının havalenameleri tanzim edilmek üzere, bildirilmesi lüzûmu Maliye Nezâreti'ne işâr edilmiş olmağla bu husûsun sûret-i salimede cereyanina kemâl-i ehemmiyetle nezâret ve icrây-1 icâb1 me'mûrin-i mülkiyeye evâmir-i lazıme-i seria itâsı himem-i behiyyelerinden mütemennadır.

fi 3 Mayls sene 336

Sadrıazam ve Harbiye Nâzırı Vekili

Damad Ferid Paşa"

17. a.y.

18. BOA, DH.1.UM.22-2/72, Bkz. Ek.V. 
Yukarıda verilen belgenin metnini muhtevî Harbiye çıkışl, 5 Mayıs 1920 tarih ve 286 sayılı tahrirat birçok vilâyete gönderilmiştir ${ }^{19}$.

Süleyman Şefik Paşa ve Erkân-1 harpleri 2 Mayıs'ta İstanbul'dan aynldılar. Izmit'teki Yavuz Zırhlısı'na karargâh kuran Süleyman Şefik Paşa, I. Alayı İzmit'in güney doğusundaki ordugâhla Sapanca'ya yerleştirdi. İzmit'te bulunan Ingiliz Tugayı ile körfezdeki donanma en büyük güvenceleriydi ${ }^{20}$.

Daha önce söz konusu edilen belgelere göre; Kuvây-1 Milliye'nin bastırılması amacıyla, İstanbul'dan henüz Kuvây-1 İnzibâtiye sevk edilememiş bulunan yerlerde, bu Ordu hakkındaki kararname hükümlerine uygun olarak kurulacak olan gönüllü kıtalar hakkında, memleketin dört bir tarafına tahrirât gönderilerek, gerekli işlemlerin yapılması istenmişti. Fakat, ülkenin birçok yerinde bu emirlerin yerine getirilmediğini görmekteyiz. Bunun çok çeşitli sebepleri vardır. Bazı imkânsızlıklar sebeplerden biri olabileceği gibi, Hilâfet Ordusu'na sempati duyulmaması çok daha önemli bir etken olsa gercktir.

Edime Valisi 31 Mayıs 1920'de Dâhiliye Vekâleti'ne gönderdiği tahrirât'ta Edirne Vilâyeti'nin durumunun kararname-i mahsûs hükmüne uygun gönüllü kıtaları kurulmasına müsait olmadığını, bu yüzden emrin tamim edilmemiş olduğunu arzediyordu.

Edime Valisinin bu tahrirâtı aşağıda aynen verilmiştir ${ }^{21}$ :

"Edime Vilâyeti

Umûmî 6651

Husûsî 640

Dâhiliye Nezâret-i Celilesine

Devletlü Efendim Hazretleri

İdâre-i Umûmiye-i Dâhiliye Müdiriyeti ifadesiyle vârid olan 6 Mayıs 336 tarihli ve 130 umûm numrolu tahrirât-1 aliyye-i nezâretpenahîleri celilidir. Vilâyetin vaziyyet-i hazırası icâbınca buralardan kararname-i mahsûsu hükmüne tevfikan gönüllü kıtaâtı teşkil ve tertibine imkân-1 müsâade olmadığı nazarı-1 dikkate alınarak işbu emrin tamim edilmemiş olduğu arzolunur. Olbabda emr ü ferman hazret-i menlehül-emrindir.

19. BOA, DH.1. UM.22-2П2. Bkz. Ek. Va.

20. Zeki Sarhhan, Kurtuluş Savaş1 Günlüğü III, Ankara 1986, S.27.

21. BOA, DH.I. UM.22-2/72. Bkz. Ek.VI. 
Yukarıdaki belgenin muhtevası 6 Haziran 1920'de Nâzır Vekili Reşâd Bey tarafından Harbiye Nezâreti Vekâleti Celilesi Cânib-i Âliyesine, yazılmıştır ${ }^{22}$.

İstanbul'daki milliyetçi propagandaların da etkisiyle, halk Kuvây-1 İnzibatiye'ye sıcak bakmayınca, Türk'ü Türk'e düşürerek çıkacak iç savaştan yararlanmayı düşünen İngilizler, Misir'da bulunan esirlerden otuzbinini Istanbul'a getirerek, Hilâfet Ordusu'nda görevlendirmek amaciyla, Selimiye ve diğer kışlalara yerleştirdiler ${ }^{23}$.

Perişan bir durumda olan bu esir, subay ve erler, çok büyük bir maddi ihtiyaç içinde olmalanna rağmen, Hilâfet Ordusu'nda görev almayı reddettiler. Yanılıp, katılanlar olduysa da, kısa bir süre içinde pişman olarak Kuvây-1 Milliye'ye dâhil oldular.

Kuvây-1 İnzibâtiye efrâdından olup, memleketi Daday kazasına gitmek üzere Bolu'ya uğrayan Mehmed Ağa isimli şahısla, Derdli Gazetesi muharriri mülâkat yapmış ve bu görüşme Gazete'nin 21 Haziran 1920 tarihli nüshasında yayınlanmıştır. Bazı tesbitlerini ilginç bulduğumuz sözkonusu mülâkatı aşağıda veriyoruz $z^{24}$ :

\section{"BİR MÜLÂKAT}

Muharrir: Kuvây-1 İnzibâtiye'ye ne sûretle dahil oldunuz ve İstanbul'dan ne vakit hareket ettiniz?

Mehmed: Ben harb-i umûmîde silâh altına alınmışdım. İngilizler'e esir düşdüm. Üç seneden beri Selânik'de bulunuyordum. İngilizler esir Türk askerlerinden bin kişiyi sûret-i mahsûsada İstanbul'a getirdi. "Anadolu'ya Bolşevikler gelmiş, çoluğunuzu çocuğunuzu kesiyorlar. Sizi silâhlandınp Anadolu'ya göndereceğiz dediler. Ingilizler bize her türlü eziyet yapıyorlar ve bizi hayvan gibi istihdâm ediyorlardı. Bittabi bu heriflerin sözüne inanmadık. Istanbul'a geldiğimizde Hilâfet Ordusu namı altında toplanan birtakım serserilerin Bolu ve Düzce ve Gerede'de birçok haneleri yağma ettiklerini ve 300'e yakın Anadolu yavrusunu boğazladıklarını duymuştum. İstanbul halkı "Bolu ve Düzceliler'e lânetler yağdınyor ve teslim olan askeri canavarcasına öldürenler nasıl mahluktur" diyorlardı. Türkler'in iyi olmasını hiçbir zaman istemeyen İngilizler'in, bizi Ańadolu halkı ile çarpışmak için alelacele Selânik'den vapurla İstanbul'a getirmesinden ve İstanbul'da herkesin silâhını topladığı halde, bizi silâhlandırıp nezâreti altında İzmit'e sevketmesinden, bizi birbirimize kır-

22. BOA, DH.I. UM. 22-2/72. Bkz. Ek. VIa.

23. Karabekir, a.e., S.663.

24. Derdli, 21 Haziran 1336/13 Şaban 1338, numro.13, S.1-2. Ek.VII. 
dırmak ve el altından kendi çorabını örmek istediğini anladığımız esir arkadaşlanmızla İzmit'e geldiğimiz vakit, silâh ve cebhanelerimizle Kuvây-1 Milliye'ye iltihak için sözleştik. Kavl ü karar ettik. İngilizler bizi Beyazid Meydanı'nda Harbiye Nezâreti'nde alaydan yetişme birkaç zabitin nezâretine verdi. Orada 500 mevcudlu Kuvây-1 İnzibâtiye I. Alaylı namiyla bir tabur teşkil ettiler. İngilizler her birimize 30 lira verdi ve Haziranın 4. günü (4 Haziran 1920 Cuma) Haydar Paşa'dan trene bindik ve İmit'e geldik. 8 mitralyöz, 6 top, 200 sandık cebhane, 60 kadar ester vardı. İngilizler bizi tel örgü içine aldı. Akşam yemekten sonra nöbetçi çavuş ve onbaşımızla sözleştik. Gece zâbitler uyuduktan sonra mitralyöz ve toplarla cebhaneleri hayvanlara yükletip, olduğumuz yerden kimseye sezdirmeksizin savuşmağı kararlaştırdık. Nöbeti onbaşısı gece saat 6'da, kulağ ${ }_{1}$ kirişti olan bizlere hazırlanın diye haber verdi. Cebhaneleri, top, mitralyözleri mekari hayvanlanna yükledik. 200'ü mütecaviz asker İngilizler'i ve başımızdaki alaylı zâbitleri şübhelendirmeyecek tertibat dâhilinde firara muvaffak olduk.

Ve izbe yollardan yürümek ve gerimizi taht-1 teminde bulundurmak sûretiyle, SABANCA taraflanna doğru yol aldık. Nihayet Kuvây-1 Milliye'ye tesadüf ederek maksadımızı bildirip, silâh ve cebhanelerimizi tamamen teslim ederek iltihak ettik.

Bu sûretle, anayurdumuza fedakâr kardaşlarımıza kavuşduk. Kuvây-1 Milliye kumandanı bizlere kuzu kestirdi ve siz esâretten geliyorsunuz, ananızı çoluk-çocuğunuzu henüz görmediniz, memleketinize gidin, Onlara da kavuşun, istirahattan sonra arzu ederseniz tekrar gelirsiniz ve beraber çalışınz dediler. Biz ise, memleketimize göz diken ve bizi birbirimize kırdırmak için çalışan İngilizler'i toprağımızdan koğmak için bizde çalışacağız, memleketimize şimdi gitmek istemiyoruz dedik. Kumandan; "Evlâdlar siz 3-4 senedir ananıza, âilenize ve evlâdlarınıza hasretsiniz. Bir müddet olsun memleketinizde durunuz. Sonra gelirsiniz" dedi. Bizim arabalanımızı ve bineceğimizi temin etti. Dün akşam Bolu'ya geldim. Yarn alessabah Gerede tarikiyle memleketim olan DADAY'a gideceğim. Bir ay sonra tekrar dönüb, düşmanlarla çarpışacağım. Artık düşmanlanmızın mel'anetini anlamayan kalmadı. Yalnız hayret ettiğim birşey var ise, biz esârette olduğumuz halde İngilizler'in mel'anetini anlıyoruz ve İstanbul'da büyüğünden küçüğüne vanncaya kadar herkes memleketimizi kurtaracak ancak, Kuvây-1 Milliye'dir diyerek, büyük bir duygu peşinde koşuyor. Bolu ve Düzceliler nasıl oluyorda bu doğru yoldan şaşıyor.

Bir de şurasını söylemeyi unutacaktım. Düzce'nin köylerinden birinde kalmıştım ve size anlatığımı oradaki köylüden misafir odasına gelenlere anlatmıştım. Hepsi gözyaşı dökerek yaptıklanna nadim oldular ve âlem-i İslâm nazannda lekelendiklerinden dolayı müteessir oldular. Şimdi herkes bu lekeyi silmek için, çete kaydolub düşman olan serseri Yunanlılar'1 İzmit'den ve İngilizler'i İstanbul'dan koğmak için cebhelere 
koştukların, Düzce'de öğrendim ve sevindim. Hakk Tealâ Hazretleri memleketi için, dini için çalışanların yardımcısıdır. Bu gayretle inşallah toprağımızda tek düşman bırakmayacağız."

Gönüllülerden oluşturulan Kuvây-1 İnzibatiye Mürettep Tümeni'nin fertleri kalitesiz olduklanndan, yeni kurulan orduda gerekli düzen ve disiplin yoktu. Gönüllüleri bu teşebbüste bulunmaya sürükleyen çeşitli sebepler vardı. Bunlann başında, Birinci Dünya Harbi'nin getirdiği psikolojik ve iktisadî yıkım geliyordu. İşsiz ve aç, aynı zamanda bilinçsiz insanlar, para karşılı̆̆ında bu orduya giriyorlardı. Bundan dolayı, çoğu sivil olup, askerlik eğitim ve vasıflarından yoksundular ${ }^{25}$.

Mensuplannın işe yaramazlığının da etkisiyle 14 Haziran'da büyük saldınyı başlattıklarında, birliklerinin çoğu mukavemette bulunmadan Kuvây-1 Milliye'ye katılmışlar, direnen topçulan ise şiddetli saldın karşısında, yardımcıları İngilizler'le İzmit'e çekilmişlerdir ${ }^{26}$.

İzmit ve Havâlisi Kumandanlı̆̆ı'nca, özel bir görevle Bolu'ya gönderilen Erkân-1 Harp Binbaşısı Hayri Bey ${ }^{27}$ de bu arada, Kuvây-i İnzibâtiye destekli âsi ve Türk milliyetçilerinin yoğun çatışmalarının sürdüğü cephede öldürülmüştü. Harbiye Nezâreti'nin 9 Haziran 1920 tarihli, Binbaşı Hayri Bey'in ailesine Kuvâyı İnzibâtiye Karamamesi gereğince, tahsis olunacak maas ve mükafat hakkındaki tezkeresi Meclis-i Vükelâ'nın 247 sayılı toplantısında okunmuş ve konu karar bağlanmıştı. Söz konusu mazbatanın sûreti aşağıda aynen verilmiştir ${ }^{28}$.

25. Türk Istiklâl Harbi VI, Istiklal Harbinde Ayaklanmalar (1919-1921), Gnkur. Harp Tarihi Bşk.lığı Resmi Yayınlan, Ankara 1974, S.122.

26. Ali Fuat Cebesoy, Milli Mücâdele Haturaları, Istanbul 1953, S.412; Türk Istiklâl Harbi VI, S.133.

27. Birinci Düzce-Bolu Ayaklanması Ozerine, bölgeye Mustafa Kemâl Paşa tarafından bir Hey'et-i Nasîha gönderilmişti. Binbaşı Hüsrev (Gerede) Bey başkanlığındaki bu heyet Gerede yakınlarında asilerce tuzağa düşürülmüştü. Binbaşı Hayri Bey'in Düzce'ye geldiği günlerde arkadaşlanıla birlikte Düzce hapishanesinde bulunan Hüsrev Bey, sonradan kaleme aldığı hatıralannda, Hayri Bey ile ilgili bazı anılarından bahsetmektedir. Bunlardan birinde; "Osmanlı ordusunda tanıştığım Erkân-1 Harp Binbaşı, Hayri Isyân cephesine gitmeden beni görmeğe hapishaneye geldi. Kendisine yüksek tahsil görmüs bir Türk Erkân-1 harbi olarak böyle bir vazifeyi nasıl kabul ettiğine hayret ettiğimi söyledim. Asayişi temin için geldiğini söylemekle, millî bahis üzerinde münakaşadan kaçınd. Düzce, Bolu havâlisinin kendi idarelerinde kalması ve Kuvây-1 Milliye'nin de olduğu yerlere hakim olması için bir anlaşma yapılması için, Mustafa Kemâl Paşa ile kendi arasında bir tavassut yapmamı teklif gibi safsatalara saptı. Hırsının her türlü vatani ve millî hislerine üstün olduğu görülen bununla fazla konuşmaya lüzum görmedim. Istanbul'dan gelen bu Hilâfet Ordusu zabitan içlerinde de bir de makineli tüfek zabiti olduğu halde cephelerine teşkilat yapmaya gittiler" demektedir. Bkz. Hüsrev Gerede, Bolu Isyân, Ankara Universitesi Türk Inkilâp Tarihi Enstitüsü Arşivị, Arşiv No, 21/3001-3005. S.11.

28. BOA, Meclis-i Vükelâ, 219. Bkz. VIII. 


\author{
"Tebliğ olunduğu devair: \\ Harbiye Tarih-i tebliği: \\ 21 Haziran 336

\section{Meclis-i Vükelâ \\ Müzâkerâtına Mahsûs Zabıtnâme \\ Hulâsa-i Meâli}

Tarih

Sira numrosu

4 Sevval 1338

247

21 Haziran 1336

İzmit ve Havâlisi Kumandanlığı tarafindan memuriyet-i mahsûsa ile Bolu'ya gönderilen ve Kuvây-1 bagiye tarafından ahiren mahdûmiyle beraber salben \$̧ehid edilmiş Erkân-1 Harb Binbaşısı Hayri Bey'in ailesini Kuvây-1 İnzibâtiye Karamâmesi mucibince tahsis olunacak maaş ve itâsı icâb eden mükâfât-1 nakdiye hakkında Harbiye Nezâreti'nin 9 Haziran 1336 tarihli tezkeresi okundu.

\title{
Karan
}

Mumaileyh Hayri Bey'in ümerây-1 askeriyeden olması cihetiyle, mezkûr kararname hükmünce ailesine bin lira mükâfât itâsı ve eytâm ve erâmiline de kezalik kararname-i mebhûs ahkâmına tevfikan muktazi maaşın sür'at-i tahsisi zımnında mu'amele-i lazimenin ifâsı husûsunun cevaben nezâret-i müşarünileyhe tezbiri tezekkür kılındı"

Devletin mali sıkıntılar içinde olduğu bu dönemde, Kuvây-1 İnzibâtiye için ayrılan olağanüstü ödenek, nereden karşılanıyordu. Hayri Bey örneğin de olduğu gibi, söz konusu karamame gereği olan harcamaları kim nasıl karşılıyordu. Bunun cevabını büyük ölçüde Avrupa basınından almak mümkündür. Nitekim, Le Temps Gazetesi, Türk Milliyetçilerine karşı birçok yerde çarpışacak olan gönüllü ordusunun düzenlenmesinde İngiliz parmağı olduğunu yazarken; Le Matin de Gazetesi de, İngiltere'nin gönülllülere günde bin lirâ verdiğini yazmaktadır ${ }^{29}$.

Kuvây-1 İnzibâtiye'nin başarısızlığa uğrayarak, İzmit'e çekilmesi üzerine, bu Ordu'nun mensuplan İngilizler vasitasıyla Türk milliyetçileriyle anlaşmaya çalıştılar. Ali Fuat Paşa ile İngiliz temsilcisi görüiştü, fakat bir anlaşmaya varamadılar ${ }^{30}$.

25 Haziran'da Harbiye Nezâreti'nce verilen emirle, Kuvây-1 İnzibâtiye'nin tüm birliklerinin kuruluștan kaldınldıklan, yalnız merkez depo taburuyla, Üsküdar'da yeni kurulan taburun Hırka-i Serif'deki dağ takımının bırakıldığı, kaldırılan birliklerdeki tüm gönüllü subaylarla, emekli subay ve erlerin terhis edilmeleri bildirildi ${ }^{31}$.

29. Yahya Akyüz, Türk Kurtuluş Savaşı ve Fransız Kamuoyu, Ankara 1988, S.167; Karabekir, a.e., S.664.

30. Cebesoy, a.e., S.412-413.

31. Türk Istiklâl Harbi VI, S.137. 
Kuvây-1 Milliye'nin önünden kaçarak, İngilizler'e sığınan Kuvây-1 İnzibâtiye mensuplarının alay edilerek hemen körfezdeki vapurlara aktarılmalan, bu Ordu'yu kuranlar açısından oldukça ibret vericidir ${ }^{32}$. Maddî desteğinin büyük ölçüde İngiltere tarafından sağlandığı Halife Ordusu'nun içine düşdüğü bu durum dolayısıyla, İngiltere-Anadolu üzerindeki emellerini gerçekleştirmede artık bu kuvvetlerden yararlanamayacağını anladığından-para musluğunu kapatmıştır. Bu yüzden, büyük bir malî s1kıntı içinde bulunan Osmanlı Hükümeti, geçmişte Halife Ordusu'nda vazife yapmıs olanlarla ilgili parasal işlemleri yürütemez bir duruma düşmüştür. Bu sebeple, Meclis-i Vükelâ 31 Mart 1921'de Harbiye Nezâreti'nin isteği üzerine, zatẹn işlerliği sadece kağıt üzerinde kalmış olan Kuvây-1 İnzibâtiye Teşkilâtı'na dair 18 Nisan 1920 tarihli kararnamenin ilgâsına karar vermiştir. Söz konusu karar ile ilgili Meclis-i Vükelâ Müzâkerâtına Mahsûs Zabitnâme metni aşağıda verilmiştir ${ }^{33}$ :

"Tebliğ olunduğu devâir

Tarihi

Harbiye

21 Safer 1339

Sira Numrosu

Tarih-i tebliğ

31 Mart 1337 98

31 Mart 337

Meclis-i Vükelâ Müzâkerâtına

Mahsûs Zabitnâme

\section{Hülasa-i Mail}

Kuvây-1 İnzibâtiye Teşkilâtı'na dair olan 18 Nisan 1336 tarihli kararname askerî tekâüd ve istifâ kanununun ahkâm-1 umûmiyesine münâfî ve hazine-i celilenin tahammülü fevkinde bazı müsâadâtı muhtevî olub, idame-i cereyan ahkâmına istitâat-1 maliye gayr-1 müsaid bulunduğundan bahisle mezkûr kararnamenin ta'dîli lüzûmunu mütezammın Harbiye Nezâreti'nin 20 Mart 1337 tarihli ve 371 numrolu tezkeresi müteala olundu.

\section{Karan}

Sûret-i işâr münâsib göründügünden mezkûr karamamenin ilgâs1 zımmında iktizâ eden diğer kararname ve esbâb-1 mucibe lâ'ihalarının tanzim ve irsâli husûsunun nezâret-i müşarünileyheya cevaben işân tezekkür kılındı."

Böylece, daha önce kuruluşuna karar vermiş olan Meclis-i Vükelâ, bu sefer de Kuvây-1 İnzibatiye'yi resmen tarihe mal ediyordu.

32. Jaeschke, Türk Kurtuluş Savaşı Kronolojisi I, Ankara 1989, S.108.

33. BOA, MV-221. Bkz.Ek.IX. 
Kuvây-1 Milliye'nin lideri Mustafa Kemâl Paşa, aldığı birtakım tebirlerle, karşıt ihtilâl hareketlerini bastınp, Anadolu halkını İstiklâl ve milli birlik çerçevesinde birleştirdikten sonra, asıl düşmana yöneldi. Ve düşmanlarımızı yendi.

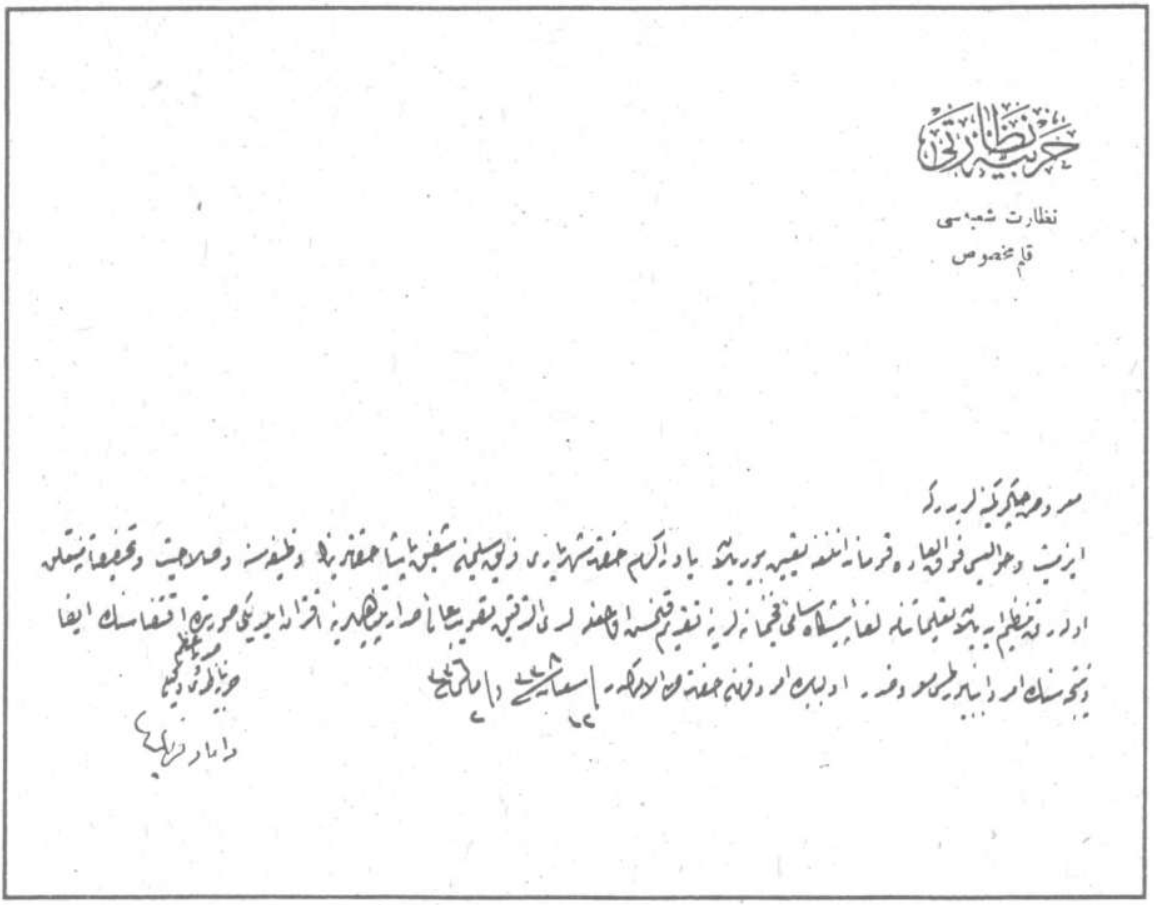




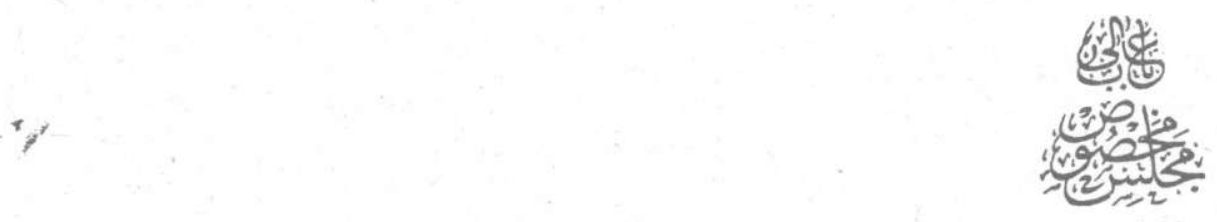

,

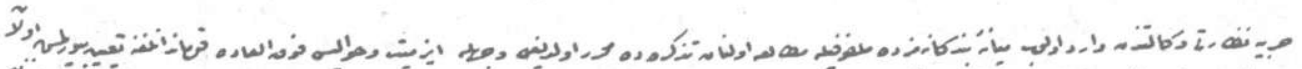

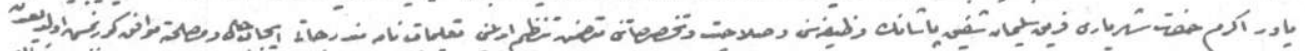

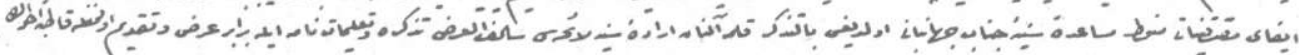

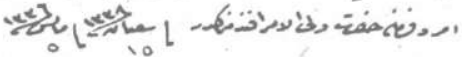

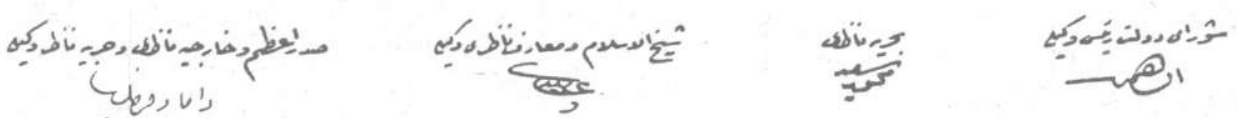

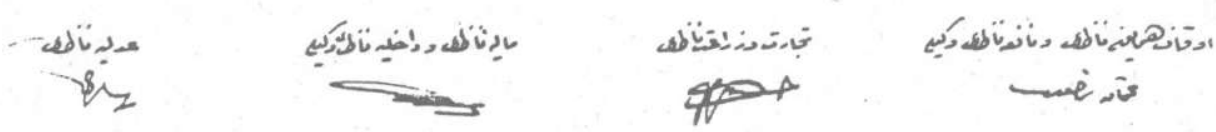




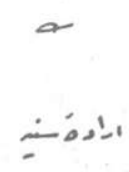

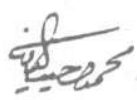
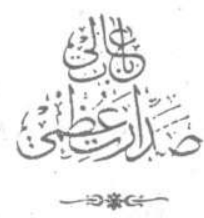

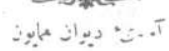

, .

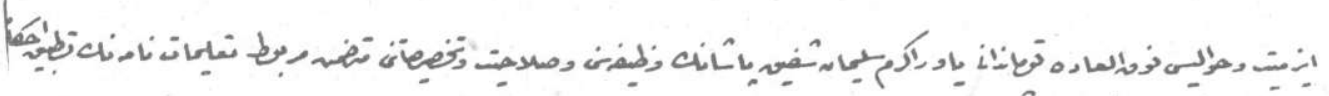

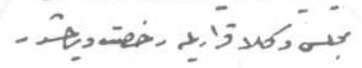

एँ

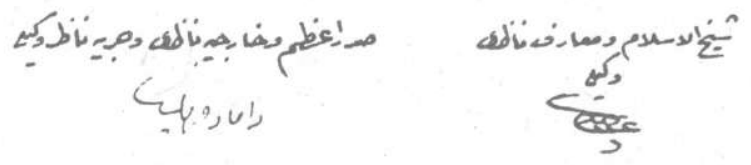

كִ

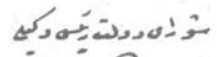

إن

C.songe

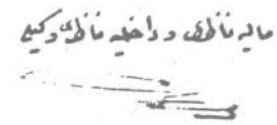

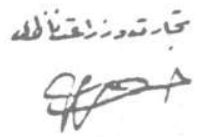

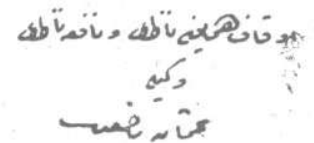


358

GÜNAY ÇAĞLAR

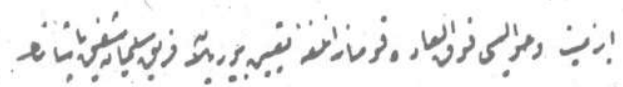

نظا: ن شبكى

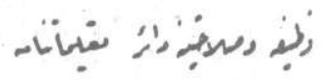
ف

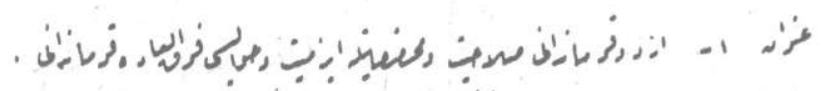

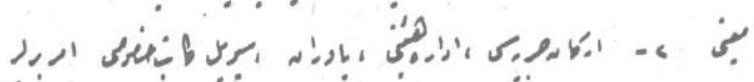

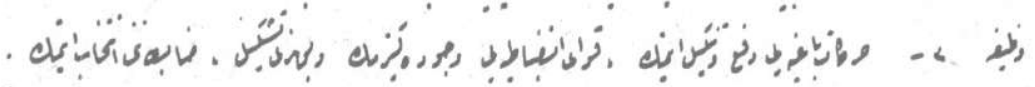

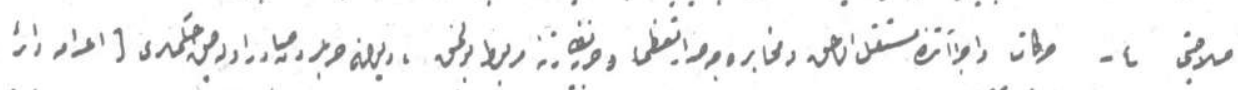

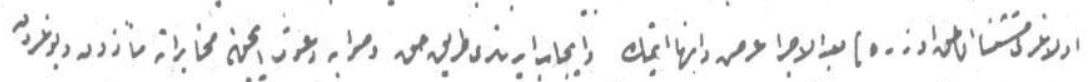

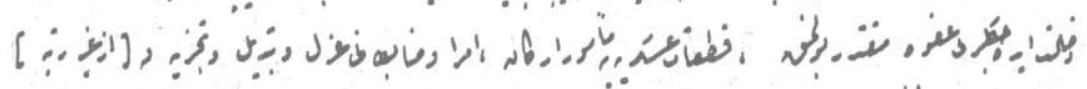

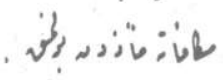

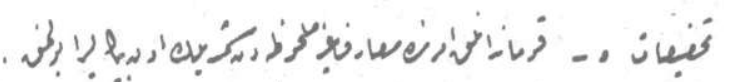

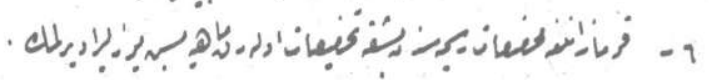

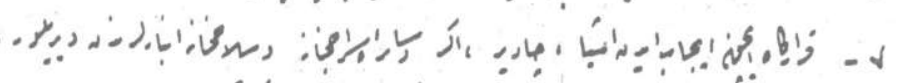

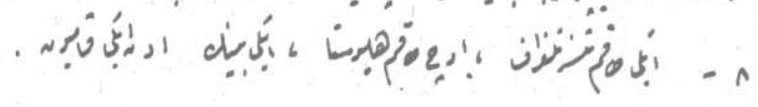




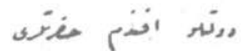

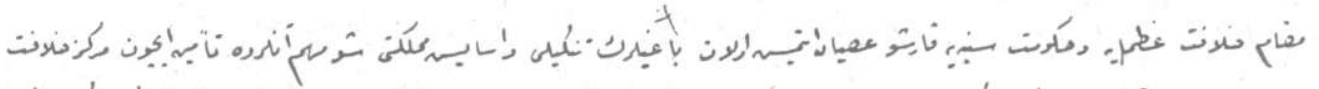

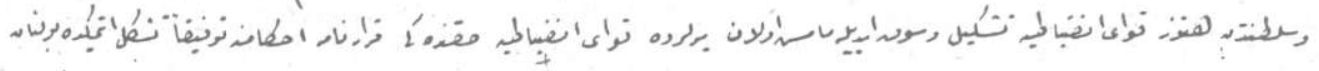

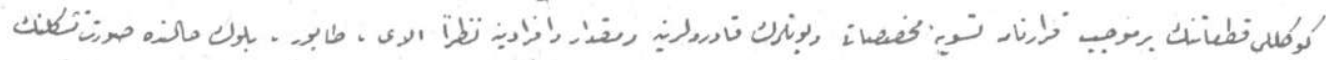

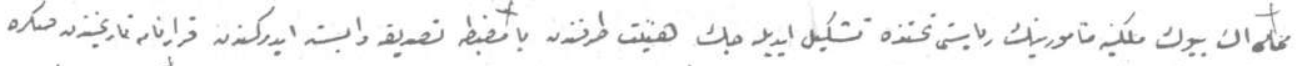

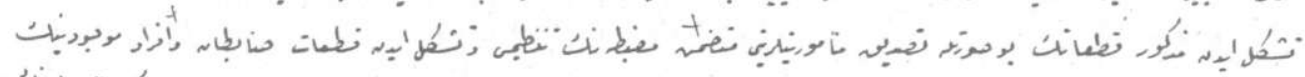

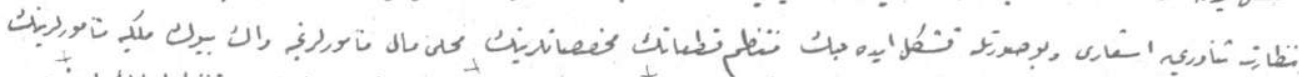

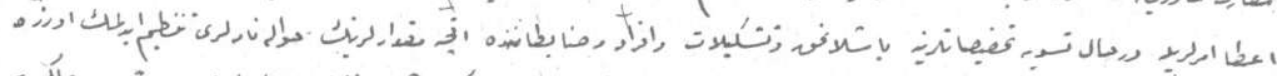

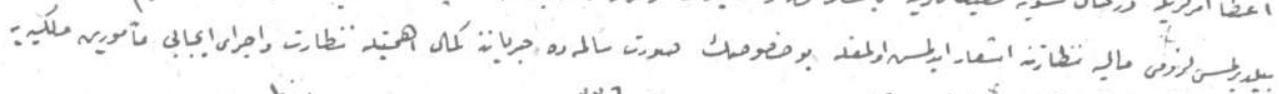

$$
\begin{aligned}
& \text { o }
\end{aligned}
$$

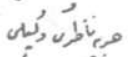

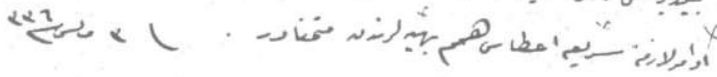

$$
\begin{aligned}
& \text { '‘v゙レ' }
\end{aligned}
$$




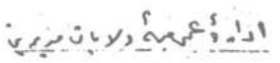

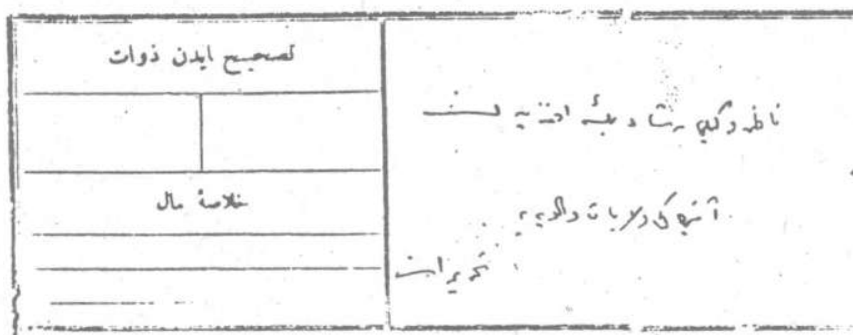

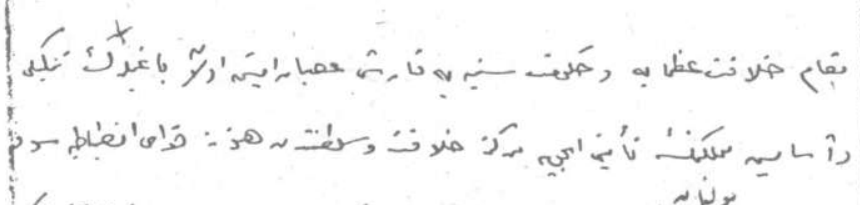

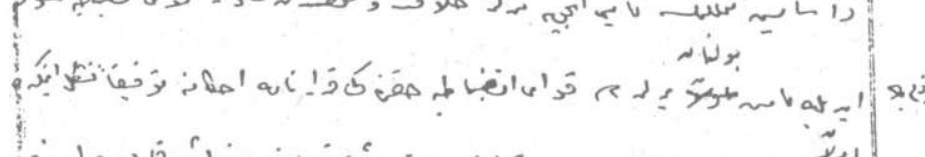

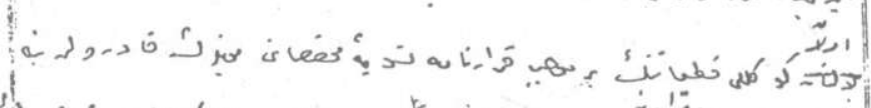

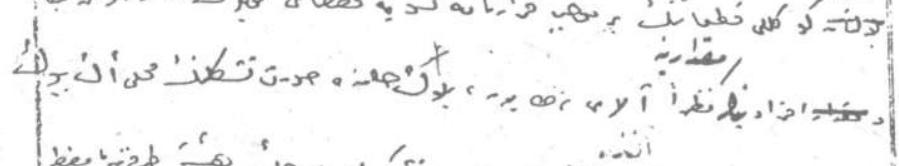

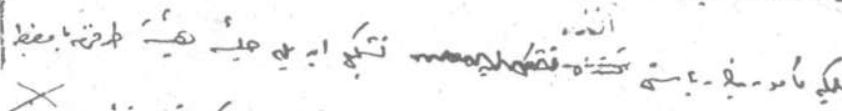

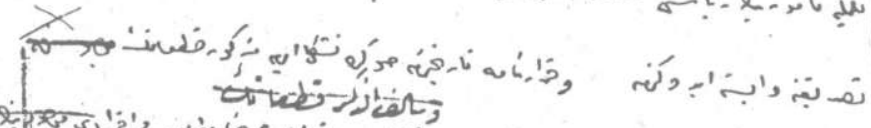

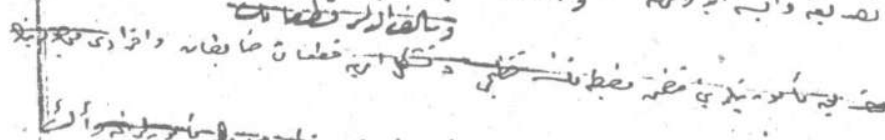

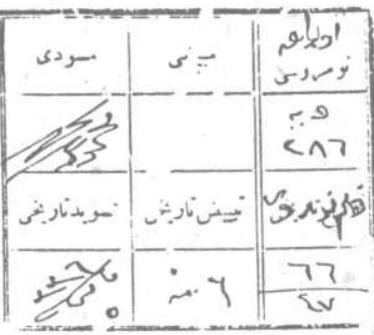

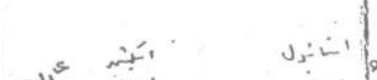

>i.

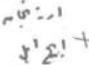

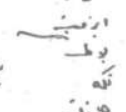

(is,

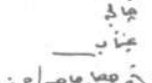

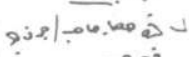

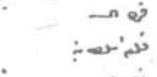

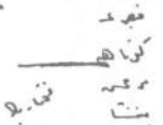

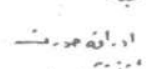

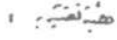

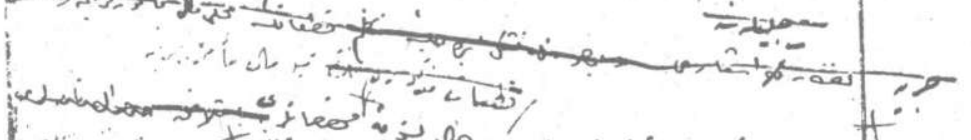

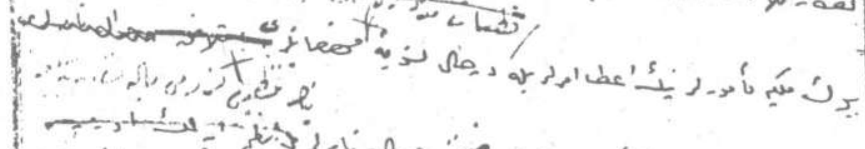

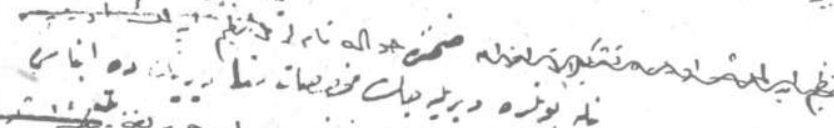

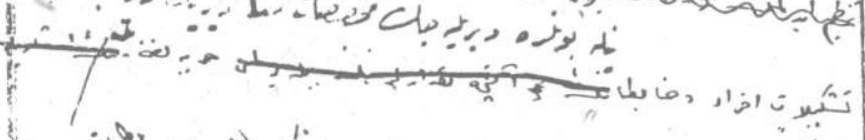

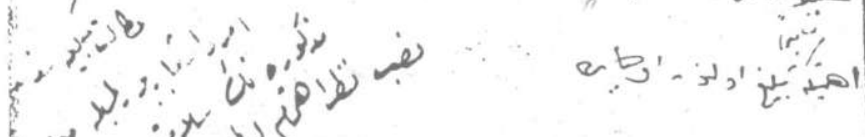

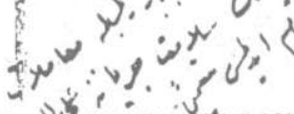
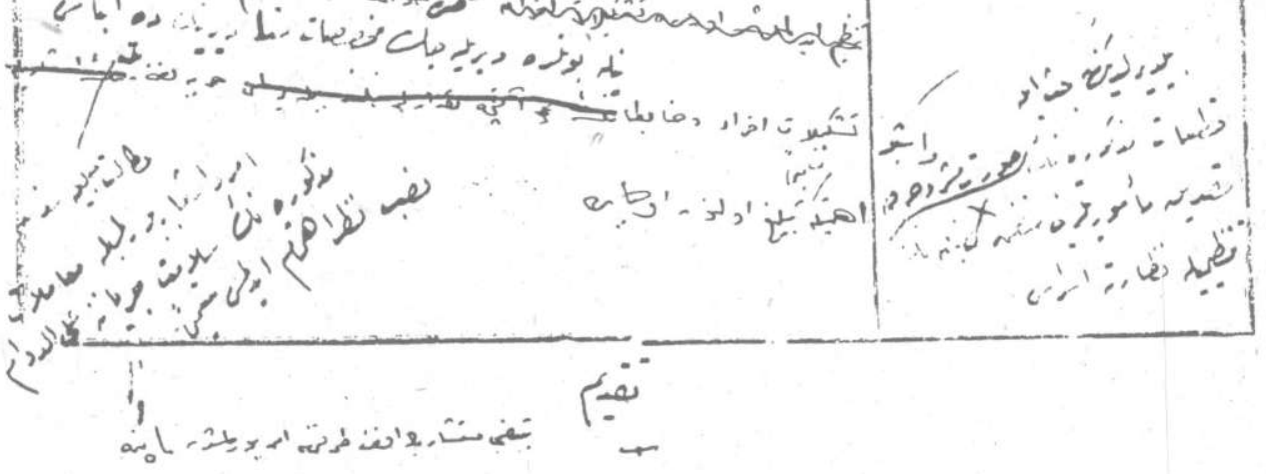

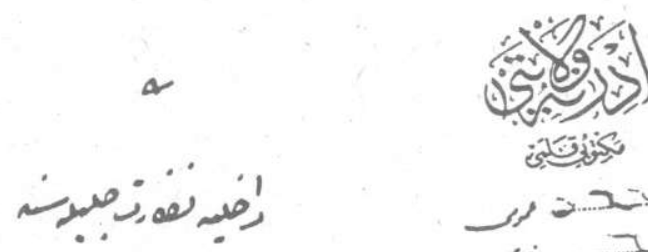

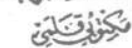

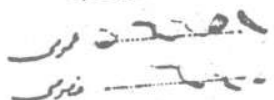

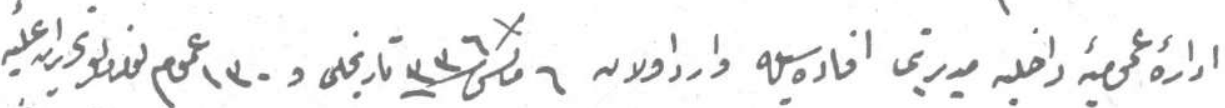

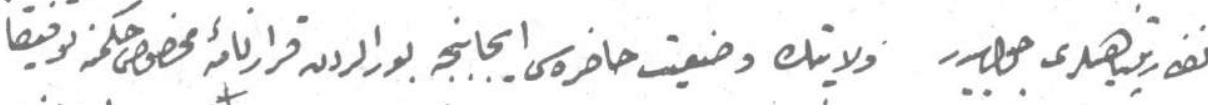

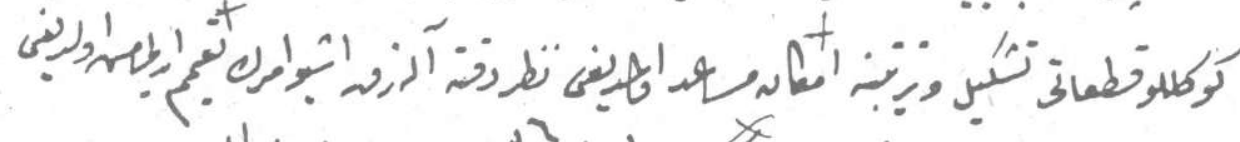

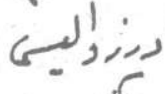

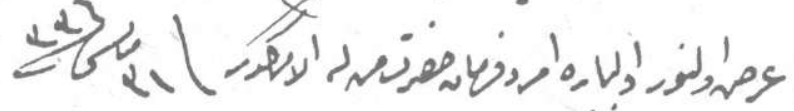
\&

رونهو 

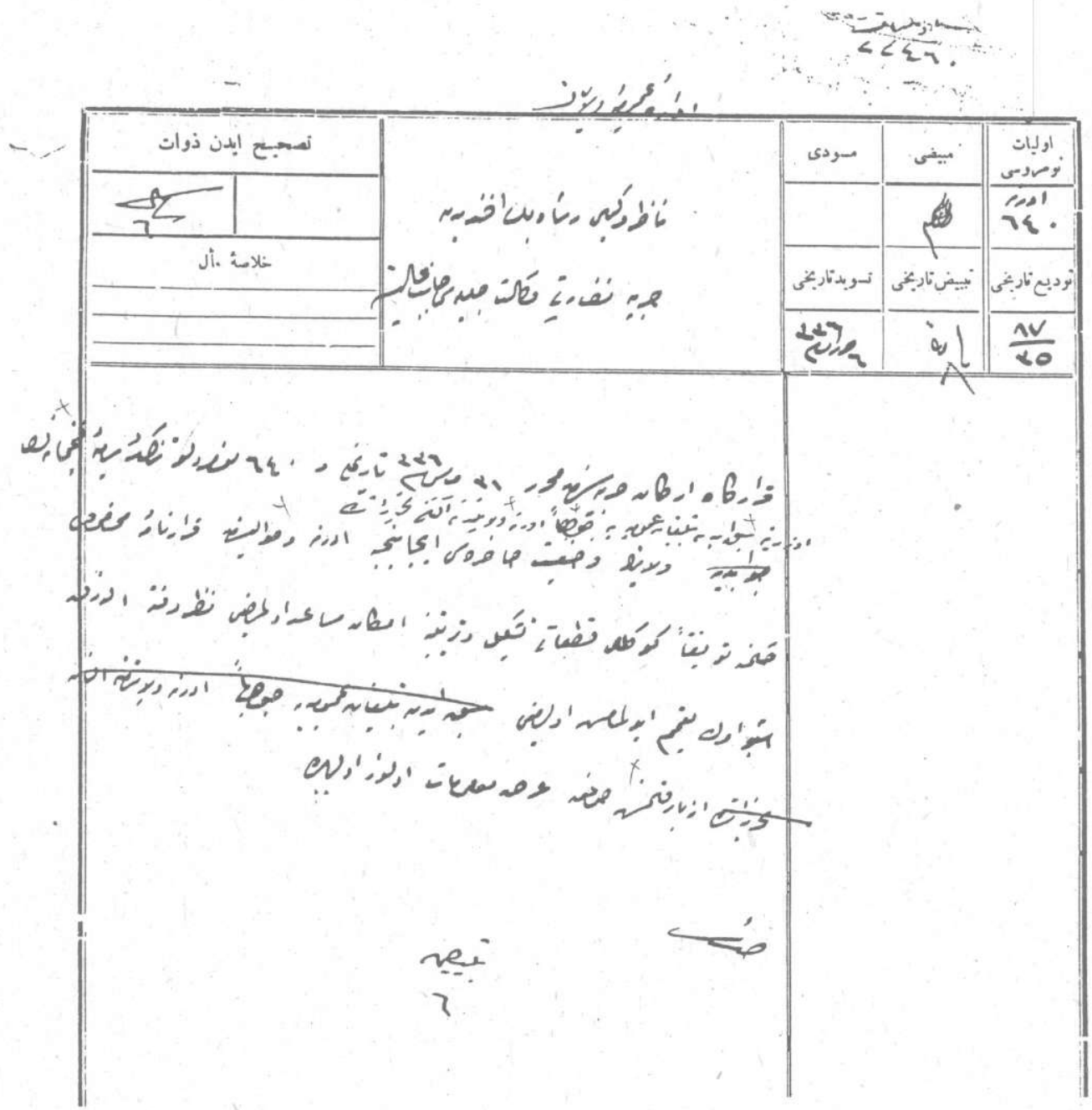


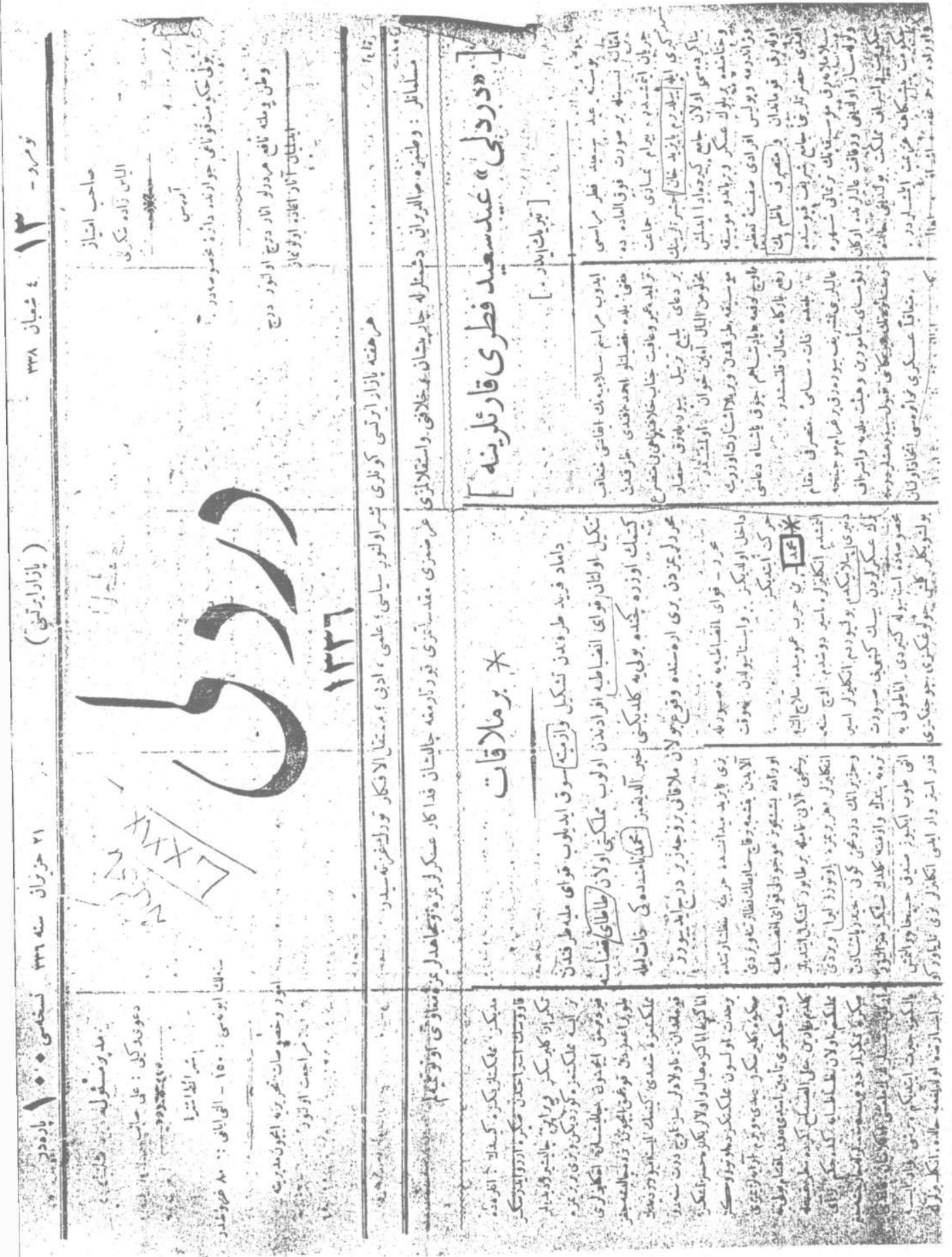




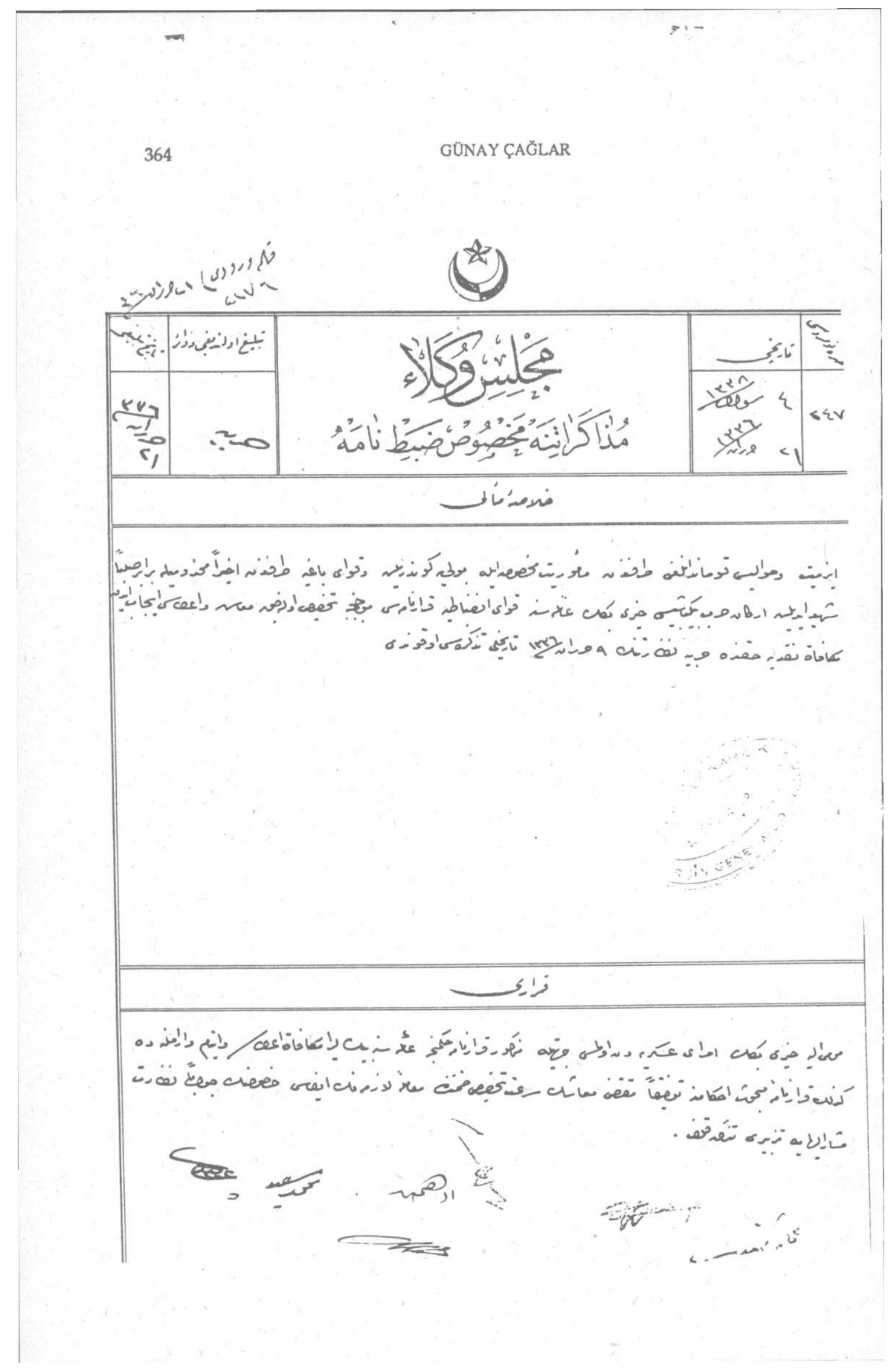




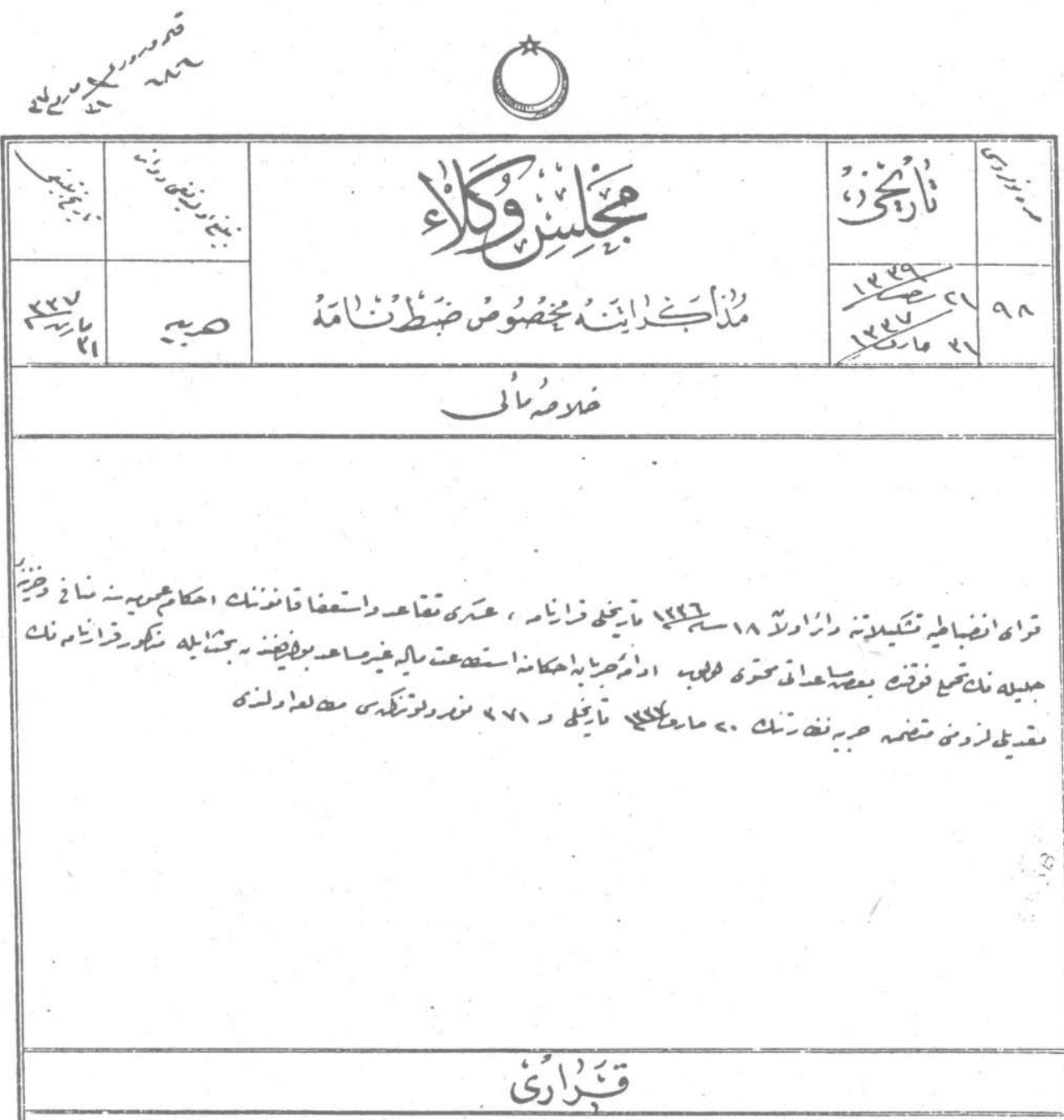

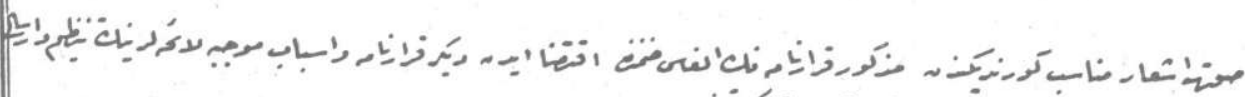

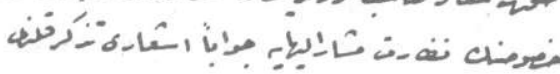

$\frac{10}{25}$

$-4.25$

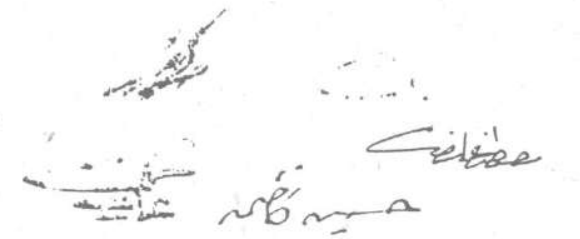




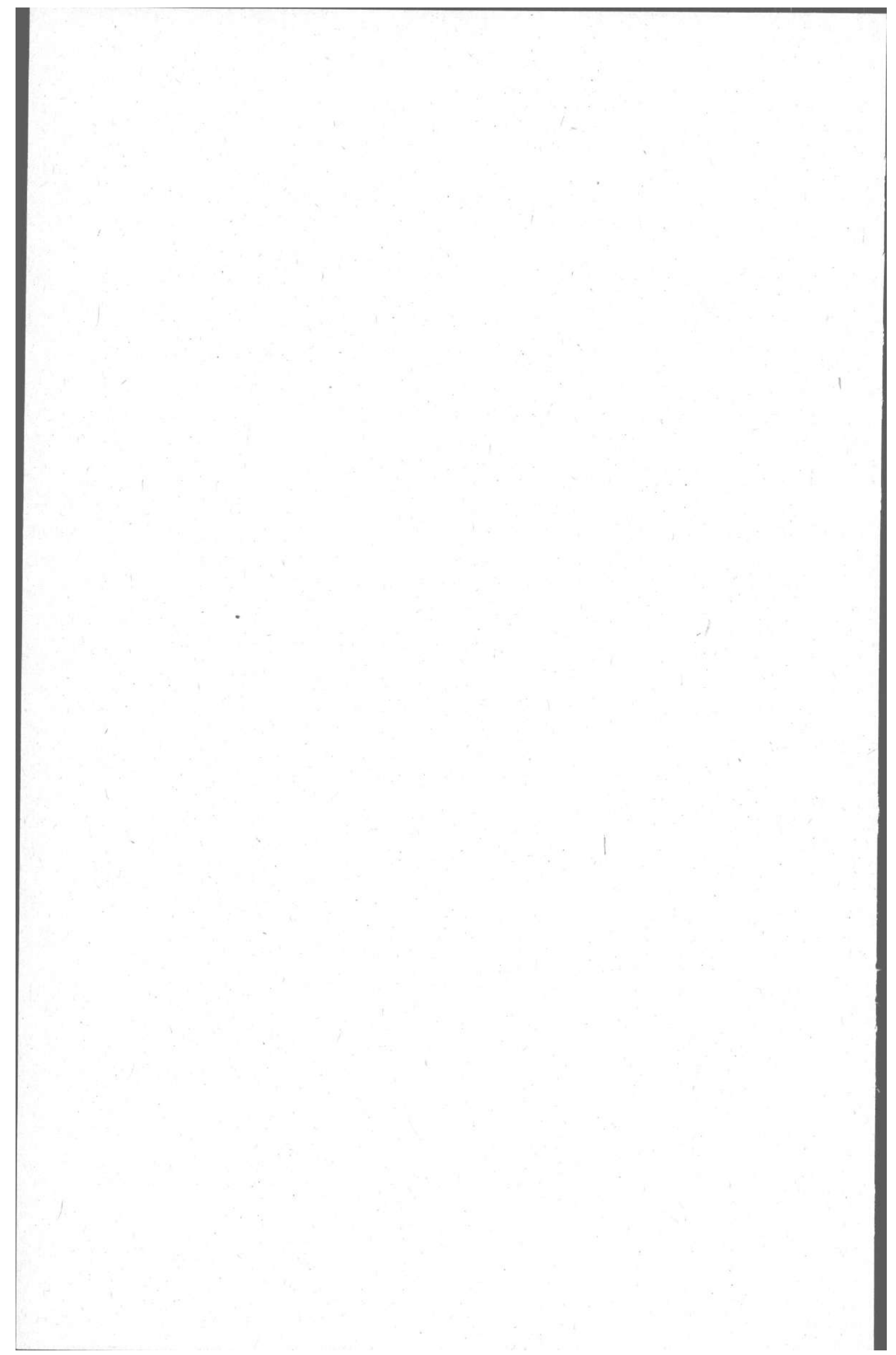

